\title{
Estrogen receptor a dependent regulation of estrogen related receptor $\beta$ and its role in cell cycle in breast cancer
}

B. Madhu Krishna ${ }^{1}$, Sanjib Chaudhary ${ }^{1,2}$, Dipti Ranjan Mishra ${ }^{3}$, Sanoj K. Naik ${ }^{1}$, S. Suklabaidya ${ }^{4}$, A. K. Adhya ${ }^{5}$ and Sandip K. Mishra ${ }^{{ }^{*}}$

\begin{abstract}
Background: Breast cancer $(\mathrm{BC})$ is highly heterogeneous with $\sim 60-70 \%$ of estrogen receptor positive BC patient's response to anti-hormone therapy. Estrogen receptors (ERs) play an important role in breast cancer progression and treatment. Estrogen related receptors (ERRs) are a group of nuclear receptors which belong to orphan nuclear receptors, which have sequence homology with ERs and share target genes. Here, we investigated the possible role and clinicopathological importance of ERR $\beta$ in breast cancer.

Methods: Estrogen related receptor $\beta$ (ERR $\beta$ ) expression was examined using tissue microarray slides (TMA) of Breast Carcinoma patients with adjacent normal by immunohistochemistry and in breast cancer cell lines. In order to investigate whether ERR $\beta$ is a direct target of ERa, we investigated the expression of ERR $\beta$ in short hairpin ribonucleic acid knockdown of ERa breast cancer cells by western blot, qRT-PCR and RT-PCR. We further confirmed the binding of ERa by electrophoretic mobility shift assay (EMSA), chromatin immunoprecipitation (ChIP), Re-ChIP and luciferase assays. Fluorescence-activated cell sorting analysis (FACS) was performed to elucidate the role of ERR $\beta$ in cell cycle regulation. A Kaplan-Meier Survival analysis of GEO dataset was performed to correlate the expression of ERR $\beta$ with survival in breast cancer patients.
\end{abstract}

Results: Tissue microarray (TMA) analysis showed that ERR $\beta$ is significantly down-regulated in breast carcinoma tissue samples compared to adjacent normal. ER + ve breast tumors and cell lines showed a significant expression of ERR $\beta$ compared to ER-ve tumors and cell lines. Estrogen treatment significantly induced the expression of ERR $\beta$ and it was ERa dependent. Mechanistic analyses indicate that ERa directly targets ERR $\beta$ through estrogen response element and ERR $\beta$ also mediates cell cycle regulation through p18, p21 cip and cyclin D1 in breast cancer cells. Our results also showed the up-regulation of ERR $\beta$ promoter activity in ectopically co-expressed ERa and ERR $\beta$ breast cancer cell lines. Fluorescenceactivated cell sorting analysis (FACS) showed increased G0/G1 phase cell population in ERR $\beta$ overexpressed MCF7 cells. Furthermore, ERR $\beta$ expression was inversely correlated with overall survival in breast cancer. Collectively our results suggest cell cycle and tumor suppressor role of ERR $\beta$ in breast cancer cells which provide a potential avenue to target ERR $\beta$ signaling pathway in breast cancer.

Conclusion: Our results indicate that ERR $\beta$ is a negative regulator of cell cycle and a possible tumor suppressor in breast cancer. ERR $\beta$ could be therapeutic target for the treatment of breast cancer.

Keywords: Breast cancer, Estrogen receptor a (ERa), Estrogen related receptor $\beta$ (ERRß), Estrogen/17beta-estradiol (E2), Promoter, Tissue microarray (TMA), ChIP, Re-ChIP, Fluorescence-activated cell sorting analysis (FACS)

\footnotetext{
* Correspondence: sandipkmishra@hotmail.com

${ }^{1}$ Cancer Biology Lab, Institute of Life Sciences, Nalco Square,

Chandrasekharpur, Bhubaneswar, Odisha 751023, India

Full list of author information is available at the end of the article
}

(c) The Author(s). 2018 Open Access This article is distributed under the terms of the Creative Commons Attribution 4.0 International License (http://creativecommons.org/licenses/by/4.0/), which permits unrestricted use, distribution, and reproduction in any medium, provided you give appropriate credit to the original author(s) and the source, provide a link to the Creative Commons license, and indicate if changes were made. The Creative Commons Public Domain Dedication waiver (http://creativecommons.org/publicdomain/zero/1.0/) applies to the data made available in this article, unless otherwise stated. 


\section{Background}

Breast cancer (BC) is the second leading cause of deaths in women worldwide. The occurrence rate of male $\mathrm{BC}$ is rare; it is the most predominant cancer in women in United States (US) [1]. It has been estimated that 2,52,710 new cases and 40,610 deaths are expected in women during the year 2017 in U.S alone [2]. BC has been recently classified based on molecular patterns of gene expression into different subtypes [3]. Luminal subtype which is characterized by the presence of estrogen receptor (ER) comprises $\sim 60-70 \%$ of $\mathrm{BC}$ and responds better to endocrine therapy i.e.; tamoxifen [4]. However, due to lack of therapy ER negative BC demands to identify molecular targets that might have therapeutic importance.

ERs are a group of nuclear receptors regulated by steroid hormone estrogen (E2). ERs are of three types; ER $\alpha$, $E R \beta$ and ER $\gamma$ [5]. In the presence of E2, ERs either as a homodimer or heterodimer bind to estrogen response elements (ERE) present in the target gene promoter to regulate its transcriptional activity [6-9]. ER $\alpha$ and ER $\beta$ expresses widely in different tissues including brain [10]. Although ER $\alpha$ causes cell migration, division, tumor growth in response to $\mathrm{E} 2[11,12]$, ER $\beta$ inhibits migration, proliferation and invasion of breast cancer cells [13-15]. Besides being a key molecule in breast cancer pathogenesis, ER $\alpha$ plays an anti-inflammatory role in brain [16].

Estrogen related receptors (ERRs) are a group of nuclear receptors family having sequence homology with ERs and act as transcriptional regulators [17]. Unlike ERs, ERRs are lesser known affected by steroid hormone estrogen. Since a decade after discovery, no natural ligand has been found for these receptors, hence called as orphan nuclear receptors [18, 19]. Estrogen related receptors (ERRs) share target genes with ERs [20, 21]. Estrogen related receptors (ERRs) are also of 3 types; ERR $\alpha, E R R \beta$ and ERR $\gamma$ [22-25]. ERRs recognize a short sequence referred as ERR- responsive element (ERRE) on target gene promoter and regulate their transcriptional activity [26-29]. The distribution of ERRs varies, although ERR $\alpha$ expresses in various tissues such as kidney, skeletal muscle, intestinal tract etc, but ERR $\gamma$ restrict themselves mainly in heart and kidney $[30,31]$. ERR $\alpha$ mediates cell proliferation through pS2 [21] and plays an important role in regulation of mitochondrial metabolism in breast cancer cells [29, 32]. Knockdown of ERR $\alpha$ leads to cardiac arrest in mice [33]. ERR $\beta$ expresses in early stages of mouse embryonic development [34]. Mutation in ERR $\beta$ leads to autosomal recessive non syndromic hearing impairment in mice [35]. ERR $\beta$ acts as tumor suppressor in prostate cancer by up-regulating p $21^{\text {cip }}$ [36]. Recent studies have demonstrated the abrogated expression of ERR $\beta$ in breast cancer cells [37]. In this study we have demonstrated that ER $\alpha$ regulates the expression of ERR $\beta$ through estrogen in breast cancer. We demonstrated the elevated levels of ERR $\beta$ in normal breast tissues and $\mathrm{ER}+$ ve breast tumors compared to breast carcinoma and ER-ve breast tumors respectively. We also demonstrated that ectopic expression of ERR $\beta$ causes significant up-regulation of p18 and p $21^{\text {cip }}$ in breast cancer cells and also arrest cell cycle in G0/G1 phase. Thus our data, suggest the tumor suppressor role of ERR $\beta$ which provide therapeutic potential to ERR $\beta$ signaling pathway.

\section{Methods}

\section{Tissue microarray}

Breast cancer tissue microarray slides (Cat No. BR 243v, BR 246a) were purchased from US Biomax (Rockville, MD, USA). The slides were stained by anti-ERR $\beta$ antibody at 1:50 dilution (sc-68879, Santa Cruz, Dallas, TX, USA) and were further processed using $\mathrm{ABC}$ system (Vector Laboratories, Bulingame, CA, USA) as described previously [38]. The images were captured under Leica microscope (Wetzlar, Germany) using LAS EZ software version 2.1.0. The slides were examined and scoring was done by an experienced pathologist. The intensity score was calculated based on staining for ERR $\beta$ and was assigned from 0 to 3 (0 indicating no staining; $1+$ weakly stained; $2+$ moderately stained and $3+$ strongly stained positively). The percentage of positively stained cells were scored as follows, 0 - no positive staining; $1+, 1-25 \%$ positively stained cells; $2+, 26-50 \%$ positively stained cells; $3+$, $51-70 \%$ positively stained cells; $4+,>70 \%$ positively stained cells. The composite score was calculated using both intensity score and the percentage of positive cells as it is a product of both scores. The composite score range was given from 0 to 12 . The samples scored $<3$ were considered as low categorized; 3-5 moderately categorized; $\geq 6$ highly categorized. The graph was plotted using composite scores using GraphPad Prism version 6.01.

\section{Cell culture and treatment}

Human estrogen receptor positive breast cancer cell lines (MCF7 and T47D) and estrogen receptor negative breast cancer cell line (MDA-MB231) were purchased from cell repository of National Center for Cell Sciences (NCCS, Pune, India) and were cultured and maintained as described previously [39]. MCF10A was a kind gift from Dr. Annapoorni Rangarajan (IISc, Bangalore, India) was maintained as previously described [40]. For estrogen treatments, MCF7 and T47D cell lines were grown in phenol red free medium for $48 \mathrm{~h}$ prior to 17beta-estradiol (E2) (Sigma-Aldrich, St. Louis, MO, USA) treatment. MCF7 cells were treated with10 and $100 \mathrm{nM}$ E2 concentrations for different time points 0,6 , 
12, 24, $48 \mathrm{~h}$. For inhibition studies, MCF7 cells were treated with $1 \mu \mathrm{M}$ of tamoxifen (Sigma-Aldrich) [41], $10 \mathrm{nM}$ E2 individually and in combination with both for $24 \mathrm{~h}$ prior to harvesting of cells. MCF7 cells were transfected with ER $\alpha$ shRNA (SHCLND-NM_000125, Sigma-Aldrich) and were culture and maintained for $48 \mathrm{~h}$ prior to further experiments.

\section{Cloning of 5' flanking region of ERR $\beta$ gene}

Genomic DNA was isolated from MCF7 cells as per the standard protocol [42]. A 1014 bp genomic fragment of the ERR $\beta$ gene, from -988 to +26 bp relative to the start sequence of exon1 (designated as +1 ) was amplified by PCR using 50-100 nanograms of genomic DNA as a template. The genomic fragment was amplified with $K p n I$ and XhoI restriction sites using primer sequences provided in Table 1 . The parameters of PCR reaction were as follows: initial denaturation $95{ }^{\circ} \mathrm{C}$ for $5 \mathrm{~min}$, 35 cycles of $95{ }^{\circ} \mathrm{C}$ for $30 \mathrm{~s}, 56{ }^{\circ} \mathrm{C}$ for $30 \mathrm{~s}, 72{ }^{\circ} \mathrm{C}$ for $1 \mathrm{~min}$ and a final extension of $72{ }^{\circ} \mathrm{C}$ for $10 \mathrm{~min}$. The amplified samples were resolved in $0.8 \%(w / v)$ agarose gel and purified using Gene elute gel extraction kit (Sigma-Aldrich) according to manufacturer's protocol. Both the purified PCR product and PGL3 basic luciferase vector were digested using KpnI and XhoI (Thermo

Table 1 List of primers

\begin{tabular}{|c|c|c|}
\hline S.No & Oligos & Sequence $\left(5^{\prime}-3^{\prime}\right)$ \\
\hline 1 & ERR $\beta$ Promoter $F$ & ACAGGTACCTTGTACTCCAGTCTGGGCGA \\
\hline 2 & ERR $\beta$ Promoter $\mathrm{R}$ & ACACTCGAGATGTCCCTGACCACACCTCT \\
\hline 3 & RT-ERa F & AGCTCCTCCTCATCCTCTCC \\
\hline 4 & RT-ERa R & TCTCCAGCAGCAGGTCATAG \\
\hline 5 & RT-ERRß F & CTATGACGACAAGCTGGTGT \\
\hline 6 & RT-ERRß R & CCTCGATGTACATGGAATCG \\
\hline 7 & RT-p21 $1^{\text {cip }} F$ & GAGGCCGGGATGAGTTGGGAGGAG \\
\hline 8 & RT-p21 ${ }^{\text {cip }} R$ & CAGCCGGCGTTTGGAGTGGTAGAA \\
\hline 9 & RT-GAPDH F & AAGATCATCAGCAATGCCTC \\
\hline 10 & RT-GAPDH R & CTCTTCCTCTTGTGCTCTTG \\
\hline 11 & ERRß EMSA Site $1 \mathrm{~F}$ & GGACAAAAATAAGGTCAAGTTTCTITGTTA \\
\hline 12 & ERRß EMSA Site $1 R$ & TAACAAAGAAACTTGACCTTATIITTGTCC \\
\hline 13 & ERRß EMSA Site $2 F$ & ATTAATGAGACAGGTCATTCATTCAGTCA \\
\hline 14 & ERR $\beta$ EMSA Site $2 R$ & $\begin{array}{l}\text { TGACTGAATGAATGAATGACCTGTCTCAT } \\
\text { TAAAT }\end{array}$ \\
\hline 15 & $\begin{array}{l}\text { ERRß chip ERE Site } \\
\text { IF }\end{array}$ & CCAGTCTGGGCGACAAGAGTGAAACTC \\
\hline 16 & $\begin{array}{l}\text { ERR } \beta \text { chip ERE Site } \\
1 R\end{array}$ & CCATTACAGTGGATTGTGGAG \\
\hline 17 & $\begin{array}{l}\text { ERR } \beta \text { chip ERE Site } \\
2 F\end{array}$ & CTCCACAATCCACTGTAATGG \\
\hline 18 & $\begin{array}{l}\text { ERR } \beta \text { chip ERE Site } \\
1 R\end{array}$ & CCAACTACCAGGAGAATAGGAGCAC \\
\hline
\end{tabular}

Scientific, Waltham, MA, USA) restriction enzymes for $4 \mathrm{~h}$ at $37{ }^{\circ} \mathrm{C}$ and purified. The restriction digested PCR product and PGL3 vectors were ligated using T4 DNA ligase (New England BioLabs, Inc., Ipswich, MA, USA) and clone was confirmed by sequencing and designated as pGL3-ERR $\beta$.

\section{Total RNA isolation and real-time PCR}

Total RNA was isolated from MCF7, T47D, MDA MB-231 and ER $\alpha$ KD cells using Tri reagent (Sigma-Aldrich). A total of $500 \mathrm{ng}$ was digested with DNase-I enzyme (Sigma-Aldrich) and was subjected to cDNA synthesis using superscript II first strand synthesis kit (Thermo Scientific). Reverse transcription PCR and Quantitative reverse transcription PCR was performed using primers provided in Table 1. $G A P D H$ was taken as an internal control and $\triangle \triangle \mathrm{CT}$ values were calculated for Quantitative reverse transcription PCR. The Quantitative reverse transcription PCR results were plotted using GraphPad Prism version 6.01 .

\section{Preparation of cell extracts and western blotting}

The whole cell lysates from breast cancer cell lines (MCF10A, MCF7, T47D, MDA MB-231) were prepared using RIPA buffer (500 mM NaCl, $5 \mathrm{mM} \mathrm{MgCl}_{2}$, $1 \% \mathrm{Na}$ deoxycholate, $20 \mathrm{mM}$ Tris- $\mathrm{HCl}$ (pH 8.0), 10\% glycerol, 1 mM EDTA, 100 mM EGTA, 0.1\% NP40, 1\% Triton X-100, 0.1 $\mathrm{M} \mathrm{Na}_{3} \mathrm{VO}_{4}, 1 \mathrm{X}$ Protease inhibitor). Approximately 20-40 microgram of protein was separated using 10-12\% SDS-polyacrylamide gel and transferred onto PVDF membrane (GE Healthcare Life Sciences, Chalfont, UK). Blots were incubated with $5 \%$ nonfat milk for blocking and were further incubated with $1 \mu \mathrm{g}$ each of subsequent antibodies ER $\alpha$ (8644, Cell signaling technology, Danvers, MA, USA), ERR $\beta$ (Sc-68879, Santa Cruz) [37], $\alpha$-tubulin (Sigma-Aldrich), cyclin D1 (2978, Cell Signaling Technology), p21 ${ }^{\text {cip }}$ (2947, Cell Signaling Technology), p18 (2896, Cell Signaling Technology) followed by corresponding HRP labeled secondary antibody. The blot was incubated with ECL (Santa Cruz) for 5 min and visualized in Chemidoc XRS+ molecular 228 imager (Bio-Rad, Hercules, CA, USA). $\alpha$-tubulin was considered as a loading control. The western blot images were quantified using Image J software (NIH, Bethesda, MD, USA).

\section{Electrophoretic mobility shift assay}

The nuclear fractions were isolated as described previously [41] using CelLytic NuCLEAR Extraction Kit (Sigma-Aldrich) and were stored at $-80{ }^{\circ} \mathrm{C}$ for further use. In-vitro DNA-protein interaction was carried out using Electrophoretic mobility shift assay (EMSA). The 
oligonucleotide sequences having ERE site present in the ERR $\beta$ promoter region were synthesized and were designated as ERR $\beta$ EMSA site 1 (-888 to -859$)$ and ERR $\beta$ EMSA site 2 (-822 to -793$)$. The forward strands of both EMSA site 1 and EMSA site 2 were labeled at 5' end with $\left[\gamma^{-32} \mathrm{P}\right]$ ATP (BRIT, Hyderabad, India) using T4 polynucleotide kinase (Promega, Madison, USA). The 5' labeled oligonucleotides were annealed with unlabeled reverse complementary strands incubating in annealing buffer (1 M Tris- $\mathrm{HCl}$ ( $\mathrm{pH} 7.5), 4 \mathrm{M} \mathrm{NaCl}, 0.5 \mathrm{M}$ $\mathrm{MgCl}_{2}$ ). The annealed oligonucleotides were incubated with nuclear extract for $20 \mathrm{~min}$ at RT in binding buffer $[1 \quad \mathrm{M}$ Tris- $\mathrm{HCl}(\mathrm{pH}$ 7.5), 50\% ( $/ \mathrm{v}$ ) glycerol, $0.5 \mathrm{M}$ EDTA, $1 \mathrm{M}$ DTT, $50 \mathrm{mg} / \mathrm{ml}$ BSA, $4 \mathrm{M} \mathrm{NaCl}]$. Poly (dI-dC) was used as a nonspecific competitor. For specific competition 100-150 fold excess unlabeled ER $\alpha$ consensus oligonucleotides were added to the reaction 10 min prior to adding 0.2 pmoles radiolabeled oligonucleotides. The DNA-protein complexes were separated in $6 \%$ polyacrylamide gel at $180 \mathrm{~V}$ for $1 \mathrm{~h}$ in $0.5 \mathrm{X}$ Tris- $\mathrm{HCl} /$ Borate/EDTA running buffer [40 mM Tris-Cl (pH 8.3), $45 \mathrm{mM}$ boric acid and $1 \mathrm{mM}$ EDTA] and was dried and autoradiographed.

\section{Chromatin immunoprecipitation assay (ChIP)}

Chromatin immunoprecipitation was performed as prescribed previously with minor modifications [43]. MCF7 and T47D cells were grown in phenol red free DMEM, RPMI-1640 (PAN Biotech GmbH, Aidenbach, Germany) medium respectively, supplemented with $10 \%(v / \mathrm{v})$ charcoal treated FBS (PAN Biotech GmbH) for $48 \mathrm{~h}$ prior to $\mathrm{E} 2$ treatment. Cells were treated with $100 \mathrm{nM} \mathrm{E2}$ for $48 \mathrm{~h}$, fixed with 1\% (v/v) formaldehyde and were washed twice with $1 \mathrm{X}$ PBS $\left(10 \mathrm{mM} \mathrm{PO}_{4}{ }^{3-}\right.$, $137 \mathrm{mM} \mathrm{NaCl}$ and $2.7 \mathrm{mM} \mathrm{KCl})$. Cells were lysed in SDS lysis buffer $(1 \%(w / v)$ SDS, $10 \mathrm{mM}$ EDTA, $50 \mathrm{mM}$ Tris-HCl (pH 8.1)) with protease inhibitor cocktail (Sigma-Aldrich) and were sonicated using Bioruptor ultrasonicator device (Diagenode S.A., Seraing, Belgium) at M2 amplitude strength. The sonicated samples were subjected to pre-clearing with protein A/G agarose beads (GE Healthcare Life Sciences). These pre-cleared samples were diluted with ChIP dilution buffer $(0.01 \%(w / v)$ SDS, $1.1 \%(v / \mathrm{v})$ Triton $\mathrm{X}-100,1.2 \mathrm{mM}$ EDTA, $16.7 \mathrm{mM}$ Tris- $\mathrm{HCl}$ (pH 8.1), $167 \mathrm{mM} \mathrm{NaCl}$ ) and divided into two equal parts IgG and IP, $50 \mu \mathrm{l}$ was taken as input and was stored at $-80{ }^{\circ} \mathrm{C}$. The IgG and IP were incubated with $1 \mu \mathrm{g}$ of anti-IgG (Diagenode), anti-ER $\alpha$ (8644 s; Cell Signaling Technology) and anti-ERR $\beta$ (sc-68879, Santa Cruz) antibodies respectively. The protein-antibody complex was extracted by incubating the samples with protein A/G agarose beads. The protein-antibody-bead complex was extracted, washed with series of different washing buffers i.e. Low salt buffer $[0.1 \%$ (v/v) SDS, 2 mM EDTA, 1\% (v/v) Triton X-100, 20 mM Tris- $\mathrm{HCl}$ (pH 8.1) and $150 \mathrm{mM} \mathrm{NaCl}]$, High salt buffer [0.1\% (v/ v) SDS, 1\% (v/v) Triton X-100, 2 mM EDTA, $20 \mathrm{mM}$ Tris- $\mathrm{HCl}(\mathrm{pH} 8.1)$ and $500 \mathrm{mM} \mathrm{NaCl}$ ], LiCl salt buffer [0.25 M LiCl, 1\% (v/v) NP-40, 1\% ( $w / v)$ deoxycholic acid (sodium salt), $1 \mathrm{mM}$ EDTA and $10 \mathrm{mM}$ Tris- $\mathrm{HCl}$ (pH 8.1)], 1X TE [10 mM Tris- $\mathrm{HCl}(\mathrm{pH}$ 8.1) and $1 \mathrm{mM}$ EDTA] and were eluted using elution buffer (1\% $(v / v)$ SDS, $0.1 \mathrm{M} \mathrm{NaHCO} 3)$. The eluted samples and input were reverse crosslinked with $5 \mathrm{M} \mathrm{NaCl}$ for $6 \mathrm{~h}$ at $65^{\circ} \mathrm{C}$ followed by incubation with $0.5 \mathrm{M}$ EDTA, $1 \mathrm{M}$ Tris- $\mathrm{HCl}$ (pH 6.5) and proteinase $\mathrm{K}$ at $45{ }^{\circ} \mathrm{C}$ for $1 \mathrm{~h}$. ChIP elutes were purified using phenol/chloroform and ethanol precipitated. DNA samples were further used to perform PCR analyses to confirm the binding of ER $\alpha$ and ERR $\beta$ on $E R R \beta$ promoter. The primer sequences used for ChIP PCR were provided in Table 1.

\section{Re-ChIP}

Re-ChIP was performed as described previously with brief modifications [44]. The sonicated samples were incubated with $1 \mu \mathrm{g}$ of anti-IgG (kch-504-250; Diagenode) and anti-ER $\alpha$ (8644 s; Cell Signaling Technology) antibodies. The antibody and protein complex was extracted using protein A/G agarose beads (GE Healthcare Life Sciences), washed with Re-ChIP wash buffer (2 mM EDTA, $500 \mathrm{mM} \mathrm{NaCl}, 0.1 \%$ (v/v) SDS, 1\% (v/v) NP40) and eluted with Re-ChIP elution buffer (1X TE, 2\% SDS, $15 \mathrm{mM}$ DTT). The eluted samples were further subjected to secondary immunoprecipitation with $1 \mu \mathrm{g}$ of anti-ERR $\beta$ (Sc-68879, Santa Cruz) primary antibody. The complex was extracted using protein $\mathrm{A} / \mathrm{G}$ agarose beads (GE Healthcare Life Sciences), washed with different buffers (Low salt buffer, High salt buffer, LiCl salt buffer, $1 \mathrm{X} \mathrm{TE})$ and eluted. The eluted samples were further subjected to reverse crosslinking followed by phenol/chloroform/isoamyl alcohol DNA isolation. The DNA samples were further used to perform PCR to confirm the binding of $E R \alpha$ and $E R R \beta$ complex on the $E R R \beta$ promoter.

\section{Transfection and luciferase assay}

MCF7 cells were grown in 24 well plates in phenol red free DMEM supplemented with $10 \%(\mathrm{v} / \mathrm{v})$ charcoal treated fetal bovine serum $48 \mathrm{~h}$ prior to estrogen (E2) treatment. Cells were transfected with pGL3-ERR pEGFP-ER $\alpha$ [41], pEYFP C1-ERR $\beta$ [37], pRL-Renilla luciferase construct (Promega) in different combinations using jetPRIME-polyplus-transfection reagent (Polyplus transfection, New York, NY, USA) according to manufacture protocol. Post $24 \mathrm{~h}$ transfection cells were treated with $100 \mathrm{nM} \mathrm{E} 2$ and vehicle and were allowed to grow for $24 \mathrm{~h}$. Luciferase assay was 
performed using Dual luciferase assay detection kit (Promega) according to manufacture protocol. Luciferase readings were obtained and were normalized with Renilla luciferase activity. The graph was plotted with normalized readings using GraphPad Prism software version 6.01 .

\section{Fluorescence-activated cell sorting analyses (FACS) for cell cycle}

MCF7 Cells $\left(3 \times 10^{5}\right)$ were grown in 6 well plates in Dulbecco's Modified Eagle Medium supplemented with $10 \%$ charcoal treated fetal bovine serum at $37^{\circ} \mathrm{C}$ for $24 \mathrm{~h}$ prior to transfection with pEYFP C1-ERR $\beta$ construct and were allowed to grow for $48 \mathrm{~h}$. Cells were further harvested and were treated with $70 \%$ ethanol for fixation, washed with ice cold $1 \mathrm{X}$ PBS thrice and were stained with DNA stain propidium iodide (PI) at $37{ }^{\circ} \mathrm{C}$. Sorting was performed and were analyzed using BD LSRFortessa (BD Biosciences) as described previously [45].

\section{Statistical analysis}

The statistical significance was analyzed using unpaired t-test for 2-group comparison. Each data represents the mean \pm SEM from three independent experiments. $P$-value $<0.05$ was considered as statistically significant. One-way ANOVA test was performed to analyze the statistical significance of multiple group comparison. $P$-value $<0.05$ was considered as statistically significant and were represented in respected figures accordingly.

\section{Results}

\section{Decreased expression of ERR $\beta$ in breast carcinoma}

The role of ERR $\beta$ in breast carcinoma has not been much elucidated with few reports published recently [37, 46]. To determine the role of ERR $\beta$ expression in breast carcinogenesis, we performed immunohistochemistry (IHC) using commercially available tissue microarray slides (TMA) purchased from US Biomax (https:// www.biomax.us/) which consist of 24 samples consisting of both breast carcinoma and adjacent normal breast tissue samples. Among the 24 samples, 4 (16.66\%) were negative and 19 (79.11\%) were positive for ERR $\beta$ staining and 1 sample was stromal tissue. Our IHC staining (composite score) showed a significant decreased expression of ERR $\beta$ in breast carcinoma tissues compared to adjacent normal breast tissues (Fig. 1a and b). We next performed western blot (WB) analyses of whole cell lysates isolated from breast cancer cells and immortalized normal breast cells. WB analyses indicated significantly low levels of ERR $\beta$ expression in breast cancer cell lines compared to immortalized breast cell line, MCF10A (Fig. 1c). The publicly available dataset, GEO accession: GSE9893 was screened and analyzed for ERR $\beta$ expression and survival of breast cancer patients. As Kaplan-Meier survival analyses showed a significant overall survival in patients with high ERR $\beta$ expression $(p=0.027382)$ suggesting the anti-tumorigenic role in breast cancer (Fig. 1d) [47]. Thus our results indicate that ERR $\beta$ expression is decreased in breast carcinoma patients, breast cancer cell lines and also has pathological implications in breast cancer.

\section{ERR $\beta$ expression is ERa dependent}

To define the role of ERR $\beta$ in breast carcinogenesis, we elucidated the expression of ERR $\beta$ in ER + ve and ER-ve breast cancer patients in tissue microarray slides (TMA). The breast cancer TMA slide consist of 24 samples with both ER + ve and ER-ve breast carcinoma and adjacent normal breast tissues. IHC showed $2(8.33 \%)$ samples that were negatively stained while $22(91.67 \%)$ samples were positively stained for ERR $\beta$ expression. Interestingly, we found that composite score for ERR $\beta$ IHC staining was significantly high in ER + ve breast cancer patients $(n=6)$ than in patients with ER-ve receptor status $(n=6)$ suggesting that ERR $\beta$ expression might be controlled by ER $\alpha$ (Fig. 2a, b). To further confirm this observation we performed western blot and reverse transcription PCR (RT-PCR) for ERR $\beta$ in ER + ve (MCF7 and T47D) and ER-ve (MDA-MB231) breast cancer cell lines and the expression of ERR $\beta$ was found to be ER $\alpha$ dependent (Fig. 2c, d). We further confirmed these findings through short hairpin ribonucleic acid (shRNA) knockdown of ER $\alpha$ in MCF7 cells. We found that depletion of ER $\alpha$ by knockdown showed a significant decrease of ERR $\beta$ expression in MCF7 cells (Fig. 3a (i \& ii), b (i \& ii) and c (i \& ii)). These results suggest for the first time that expression of the orphan receptor ERR $\beta$ is ER $\alpha$ status dependent and may have clinical significance in breast cancer pathogenesis.

\section{Estrogen dependent expression of ERR $\beta$ in ER + ve breast cancer cells}

As we have shown the correlation between ER $\alpha$ and ERR $\beta$ in ER + ve patient samples and breast cancer cells, we therefore analyzed the effect of estrogen on ERR $\beta$ expression. MCF7 cells were treated with estrogen (10 \& $100 \mathrm{nM})$ for different time intervals $(0,6,12,24 \& 48 \mathrm{~h})$ and western blot was performed. A significant increase in the expression of ERR $\beta$ (> 2 fold) was observed with estrogen treatment (100 nM) (Fig. 4a (iii \& iv)) and effect of estrogen was observed at time point as low as $6 \mathrm{~h}$ with highest expression ( $\sim 5$ fold) at $48 \mathrm{~h}$. It is to be noted that the treatment with lower concentration of estrogen (10 $\mathrm{nM})$ also showed significant change in MCF7 cells after 12 to $24 \mathrm{~h}$ (Fig. 4a (i \& ii)). However the estrogen mediated ERR $\beta$ up-regulation was inhibited with 
a
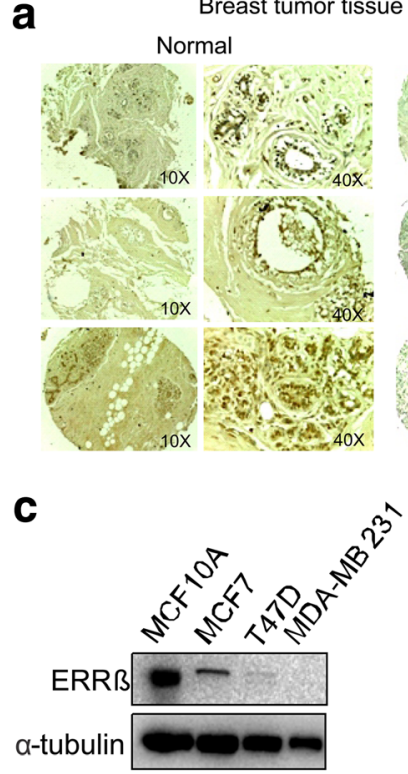

b
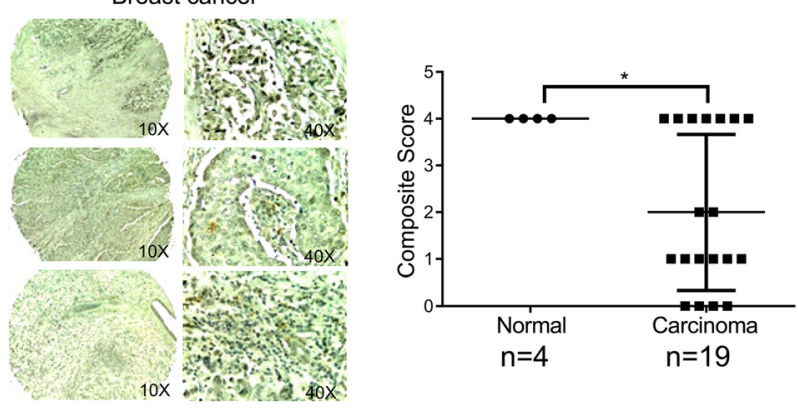

d Chanrion et.al 2008

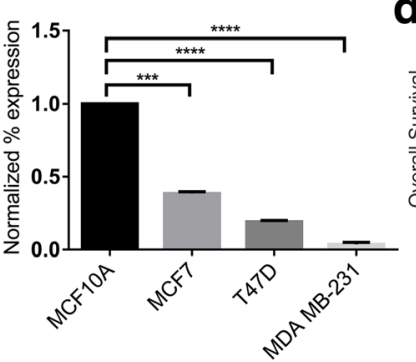

High $\mathrm{n}=101$

d

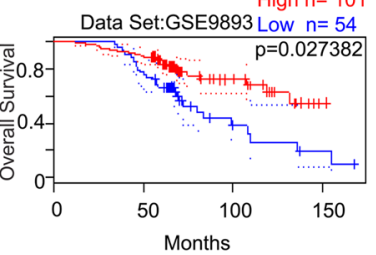

Fig. 1 Expression of ERRß in normal vs breast cancer tumor samples, cell lines and its pathological significance. a Immunohistochemical staining of tissue microarray slides using ERR $\beta$ antibody in both normal $(n=4)$ and breast carcinoma tissues $(n=19)$. Increased expression of ERR $\beta$ in normal tissues compared with breast carcinoma. $\mathbf{b}$ Graphical representation of IHC composite score of each tissue microarray sample. Composite score was calculated for each sample using both intensity score and percentage of cells positive for ERRß staining (composite score $<3$ low categorized; 3-5 moderately categorized; $\geq 6$ highly categorized). Graph was plotted using composite score and $p$-values were calculated using 2-group t-test ( $p<0.05$ considered as significant). c Western blots revealing high expression of ERR $\beta$ in normal breast cell line (MCF10A), than breast cancer cell lines (MCF7, T47D, and MDA-MB-231). Densitometry analyses of ERR $\beta$ expression in normal and breast cancer cell lines, One-way ANOVA test was performed to acquire statistical significance $\left({ }^{*} p<0.05,{ }^{* *} p<0.01,{ }^{* * *} p<0.001,{ }^{* * *} p<0.0001\right)$. $\mathbf{d}$ Kaplan-Meier survival curve of Chanrion et al. (Dataset: GSE9893) correlated higher expression of ERR $\beta$ with favorable survival $(p=0.027382)$

tamoxifen treatment (Fig. 4b). These results suggest that ERR $\beta$ expression in ER + ve breast cancer cells is estrogen dependent.

\section{ERa regulates ERR $\beta$ by binding to ERE sites present in the 5' flanking region of $E R R \beta$}

To understand the role of estrogen receptor $\alpha$ in the regulation of $E R R \beta$, the 5 ' flanking sequence of $E R R \beta$ was screened for the presence of ERE sites manually. Two putative half estrogen responsive elements (ERE sites) were found and designated as ERE site1 ( -877 to - 872) and ERE site 2 (- 810 to -805 ) (Fig. 5a). To confirm the binding of ER $\alpha$ to the putative half ERE sites present in the 5' flanking sequence of ERR $\beta$, electrophoretic mobility shift assay (EMSA) was performed. The oligonucleotides designated as ERR $\beta$ EMSA site1 and ERR $\beta$ EMSA site2 were radio labeled with $\left[\gamma^{-32} \mathrm{P}\right]$ ATP and incubated with nuclear extracts isolated from MCF7 cells. EMSA clearly shows that ER $\alpha$ can bind to both the putative sites (ERE site 1 and ERE site 2). The specificity of the protein bound to the sites was further confirmed by competing with $50-500$ fold molar excess of unlabelled estrogen response element (ERE) consensus sequence. The unlabelled ERE consensus completely abolish the DNA/protein complex suggesting the binding of ER $\alpha$ (Fig. 5b). Further chromatin immunoprecipitation assay (ChIP) was carried out to confirm the binding of ER $\alpha$ on ERR $\beta$ promoter in-vivo. MCF7 and T47D cells were treated with estrogen for $48 \mathrm{~h}$ and were subjected to ChIP procedure using ER $\alpha$ monoclonal antibody. The isolated immunoprecipitated DNA fragments were then subjected to PCR amplification. The ChIP PCR suggests the enriched binding of ER $\alpha$ on both the half ERE sites present on the $5^{\prime}$ flanking region of $E R R \beta$ during estrogen stimulation compared with the untreated samples and binding of ER $\alpha$ on ERE site 1 is stronger than ERE site 2 (Fig. 6a (i) and (ii)). However we did not observe any binding of ER $\alpha$ in the same sites in MDA-MB231 cell line as expected and used as a negative control during the ER $\alpha$ ChIP procedure. (Fig. 6c). Apart from ER $\alpha$ recruitment to ERE elements, ERR $\beta$ may also be co-recruited on its own promoter through ER $\alpha$. Previous reports have already proved that estrogen treatment lead to formation of 
a
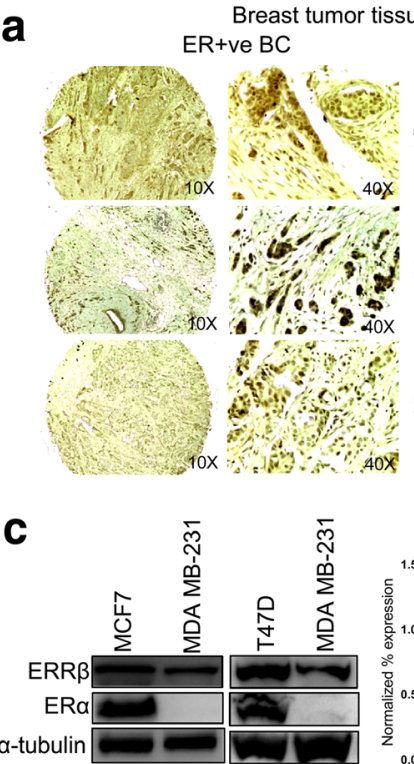

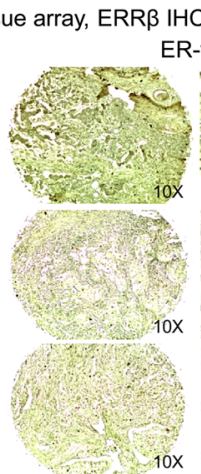
ER-ve B

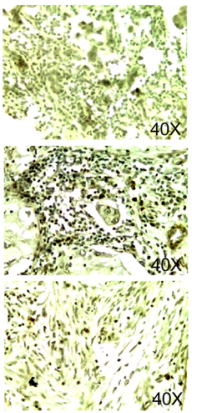

b

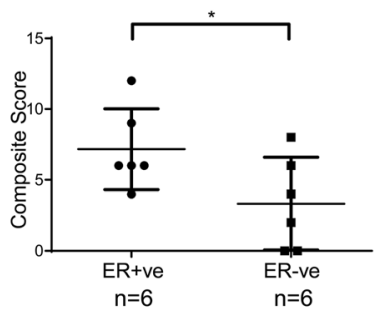

d
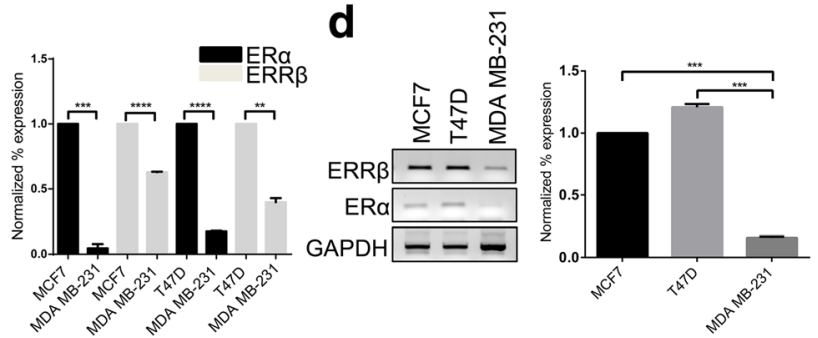

Fig. 2 Correlation of ERR $\beta$ expression with ERa in breast tumors and cell lines. a Immunohistochemical staining with ERR $\beta$ antibody in ER + ve and ER-ve breast cancer patients. Elevated expression of ERRß was found in ER + ve $(n=6)$ compared to ER-ve $(n=6)$ breast cancer patient samples. $\mathbf{b}$ Graphical representation of $\mathrm{IHC}$ composite scores of each tissue microarray sample showing significant elevated expression of ERR $\beta$ in ER + ve than in ER-ve breast cancer patient samples. Graph was plotted using composite score and $p$-values were calculated using 2-group t-test ( $p<0.05$ considered as significant). c, $\mathbf{d}$ Western blots, Reverse transcription polymerase chain reaction (RT PCR) and densitometry analysis results representing elevated levels of ERR $\beta$ in ER + ve breast cancer cells $\left({ }^{*} p<0.05,{ }^{* *} p<0.01,{ }^{* * *} p<0.001,{ }^{* * * *} p<0.0001\right)$. Statistical significance for relative gene expression (RT PCR) and normalized percentage of expression (WB) was analyzed using One-way ANOVA and unpaired t-test respectively ( $p$-value $<0.05$ was considered as significant)

heterodimer between ER $\alpha$ and ERR $\beta$ proteins [48]. Our previous results also suggest the increased nuclear localization of ER $\alpha$ in the presence of estrogen. Therefore we hypothesize that the binding of ERR $\beta$ on its own promoter may be through ER $\alpha$ in the form of heterodimer. To test this hypothesis we initially performed in-vivo ChIP assay using ERR $\beta$ specific antibody and found that ERR $\beta$ binds to the half ERE sites present on its $5^{\prime}$ flanking region in the presence of estrogen (Fig. 6b (i) and (ii)). We then performed Re-ChIP in which both the ER $\alpha$ and ERR $\beta$ antibodies were used. Re-ChIP PCR clearly showed that ER $\alpha$ along with ERR $\beta$ binds to the half ERE sites present in the $5^{\prime}$ flanking region of ERR $\beta$ in the presence of estrogen (Fig. $6 \mathrm{~d}$ ). This data clearly shows that ER $\alpha$ and ERR $\beta$ could bind directly and as ER $\alpha / E R R \beta$ heterodimer in the presence of estrogen to regulate ERR $\beta$ transcriptionally.

\section{ERa up-regulates the promoter activity of ERR}

To further confirm the effect of ER $\alpha$ on $E R R \beta$ promoter activity, we cloned the ERR $\beta$ promoter in pGL3 basic luciferase vector using Kpn1 and Xho1 restriction sites. The ERR $\beta$ promoter construct was sequenced and cloning was confirmed (Fig. 7a). pGL3-ERR $\beta$ promoter construct was co-transfected with ER $\alpha$ and ERR $\beta$ expression vector plasmid. After $48 \mathrm{~h}$ of co-transfection with $E R \alpha$, a significant increase in luciferase activity of ERR $\beta$ promoter was found (Fig. 7b). The luciferase activity was further elevated in the presence of $E R \alpha$ and $E R R \beta$ followed by estrogen treatment compared to only $E R \alpha$ and $E R R \beta$ co-transfection. However, no significant change was observed in the luciferase activity in the presence of $E R R \beta$ transfection alone (Fig. 7c). These findings suggest that ER $\alpha$ binds to half ERE sites in the promoter of $E R R \beta$ to increase its transcription. Apart from that our results also show that ERR $\beta$ along with ER $\alpha$ bind to the half ERE sites present on promoter of $E R R \beta$ gene.

\section{ERR $\beta$ regulates cell cycle in breast cancer cells}

In our present study we demonstrate that ER $\alpha$ can regulate $E R R \beta$ expression. It has been proven that ERRs share target genes with ERs and p21 ${ }^{\text {cip }}$ is a target gene of $E R \alpha$ and it has significant role in cell cycle regulation $[20,21,49]$. Hence we hypothesize that ERR $\beta$ may also regulate $\mathrm{p} 21^{\text {cip }}$ and has a significant role in cell cycle regulation. To understand the role of ERR $\beta$ in cell cycle, 


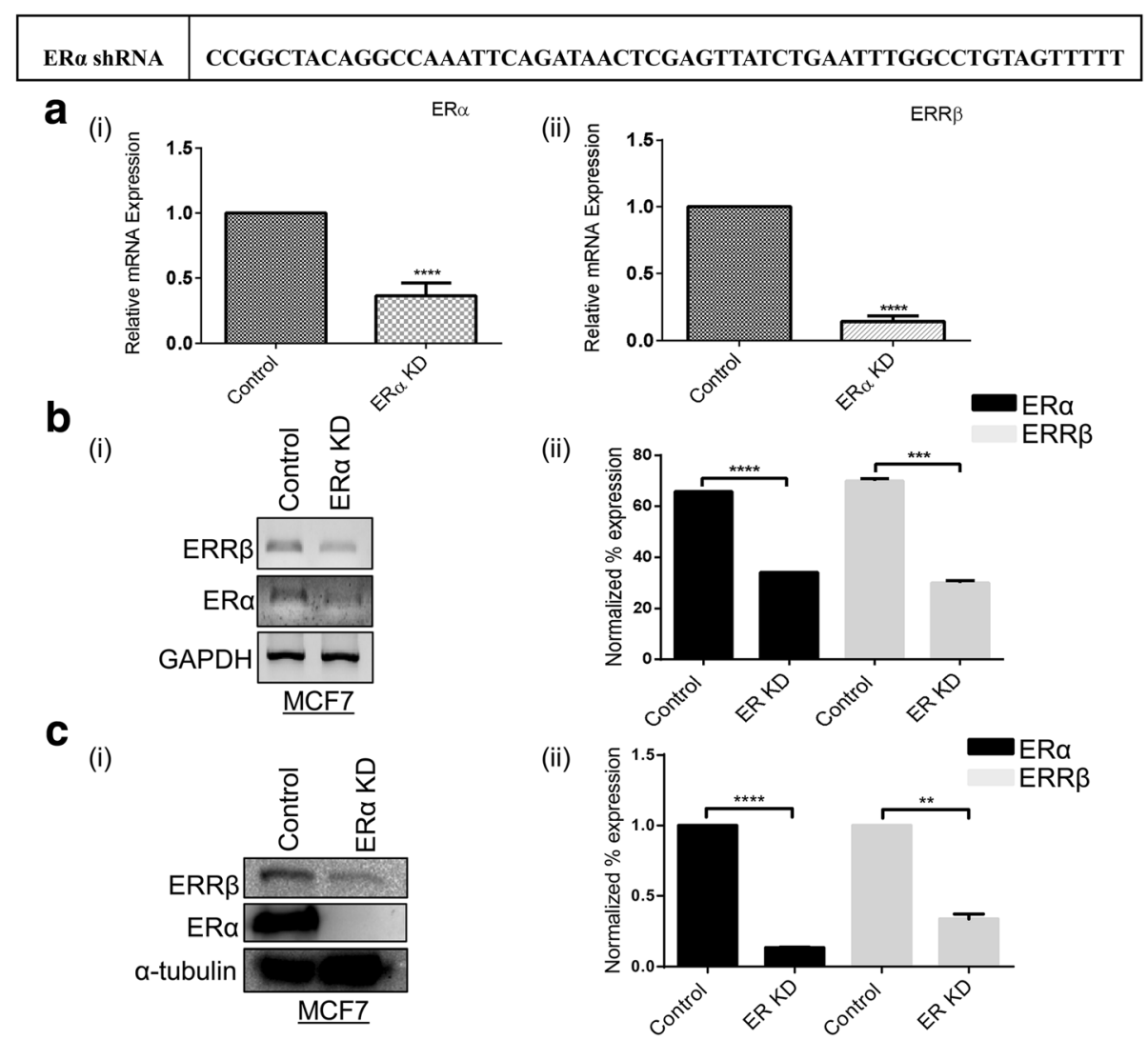

Fig. 3 Expression of ERR $\beta$ is ERa dependent. Efficient knockdown of ERa showing significant decrease in the expression of ERR $\beta$ in MCF7 cells. $\mathbf{a}$, $\mathbf{b}$ Quantitative Real-time PCR (qRT-PCR) and Reverse transcription polymerase chain reaction (RT-PCR) results showing decreased expression of ERRB in ERa depleted MCF7 cells. Housekeeping gene GAPDH treated as control and $\Delta C \mathrm{Ct}, \Delta \Delta \mathrm{Ct}, 2^{-\Delta \Delta C \mathrm{t}}$ values were calculated and graph was plotted using $2^{-\Delta \Delta C t}$ values. Fold change $\geq 2$ was considered as significant. $p$-values were calculated using 2-group t-test $\left({ }^{*} p<0.05,{ }^{* *} p<0.01\right.$, $\left.{ }^{* * *} p<0.001,{ }^{* * *} p<0.0001\right)$. c Western blot revealing the depleted expression of ERR $\beta$ in ERa Knockdown MCF7 (ERa KD) cells

we overexpressed ERR $\beta$ in ER + ve breast cancer cells (MCF7 and T47D). Forty-eight hours of post transfection, the whole cell lysates were extracted from the ERR $\beta$ expression vector and control vector transfected cells and western blot was performed. Western blot analyses showed that cell cycle proteins $\mathrm{p} 18$ and $\mathrm{p} 21^{\mathrm{cip}}$ were up-regulated whereas cyclin D1 was down-regulated (Fig. 8a). Similar results were also observed in the p21 ${ }^{\text {cip }}$ mRNA levels in both MCF7 and T47D cells (Fig. 8b, c). These results suggest the probable role of ERR $\beta$ in the regulation of cell cycle by regulating $\mathrm{p} 18, \mathrm{p} 21^{\text {cip }}$ and cyclin D1 in breast cancer cells. Furthermore, fluorescence-activated cell sorting analysis for cell cycle showed increase in G0/G1 phase cell population in ERR $\beta$ ectopically expressed cells as expected (Fig. 8d). These results proved the cell cycle regulatory and tumor suppressive role of ERR $\beta$ in breast cancer cells. The schematic representation provides an overall idea of the regulation of ERR $\beta$ and its role in cell cycle regulation in breast cancer cell lines (Fig. 9).

\section{Discussion}

ER $\alpha$ plays an important role in breast cancer progression, metastasis and treatment [50, 51]. DNA binding domain of ER $\alpha$ is highly conserved with ERRs hence can share target genes [21, 22]. ERRs involve in cell proliferation and energy metabolism [21, 29]. Expression of ERR $\beta$ was found to be constant throughout the menstrual cycle [52]. ERR $\beta$ can regulate Nanog expression through interacting with Oct4 [53] and acts as tumor suppressor in prostate cancer cells [36]. A limited literature has addressed the role of ERR $\beta$ in breast cancer. We therefore studied the possible role of ERR $\beta$ in breast cancer. We found the relative expression of ERR $\beta$ is high in immortalized normal breast cells (MCF10A), in contrast to breast cancer cell lines (MCF7, T47D, MDA-MB231) and these findings were in agreement with the previous studies [37]. Immunohistochemical staining with ERR $\beta$ showed a significant increased expression of ERR $\beta$ in normal breast tissues compared to breast carcinoma tissues. Breast cancer patients having 


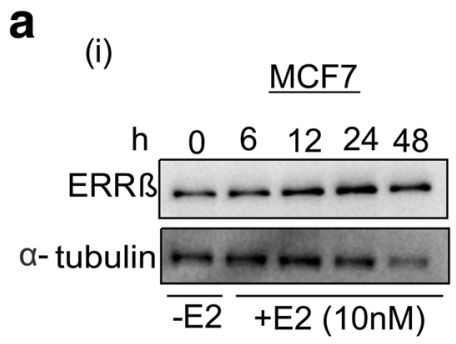

(iii)

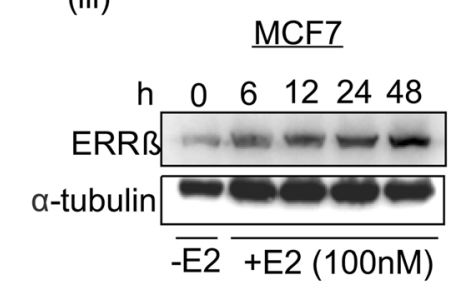

b (I)

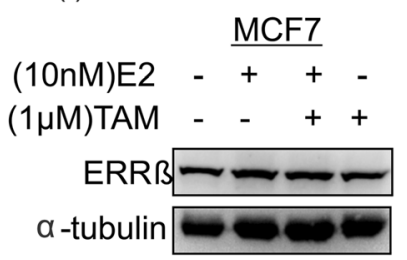

(ii)

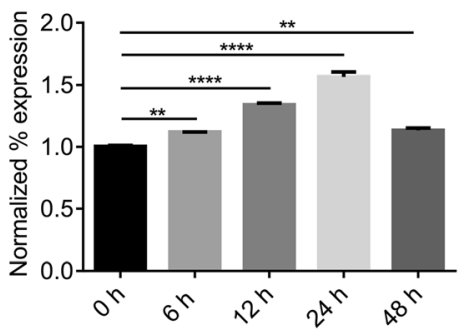

(iv)

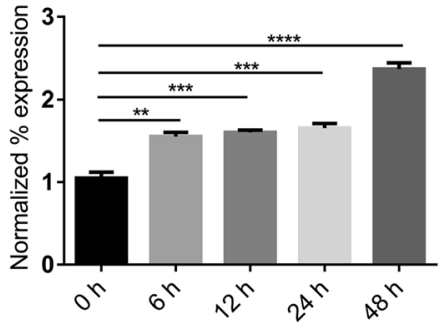

(ii)

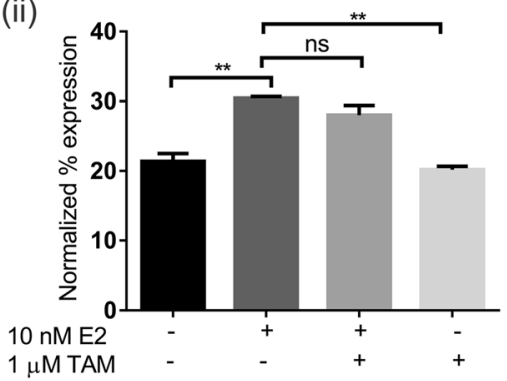

Fig. 4 Estrogen regulates the expression of ERR $\beta$. a Western blots and densitometry analyses showing up-regulation of ERR 3 upon estrogen treatment at different concentrations [10 nM (i) \& $100 \mathrm{nM}$ (ii)] for different time points $(0,6,12,24,48 \mathrm{~h})$ in MCF7 cells. MCF7 cells showed > 2 fold high expression of ERR $\beta$ upon the treatment of $100 \mathrm{nM}$ E2 treatment. $\mathbf{b}$ Combinatorial treatment of MCF7 cells with estrogen and tamoxifen decrease ERR $\beta$ expression. The association between normalized percentage expression in different groups were analyzed using One-way ANOVA test (ns- no significance, ${ }^{*} p \leq 0.05$, $\left.{ }^{* *} p \leq 0.01,{ }^{* * *} p \leq 0.001,{ }^{* * *} p \leq 0.0001\right)$

high expression of ERR $\beta$ showed better survival [47]. Both Immunohistochemical and western blot studies revealed high expression of ERR $\beta$ in $E R+$ ve breast cancers and it is dependent on Estrogen receptor status. Furthermore, reduced ERR $\beta$ expression was observed in ER $\alpha$ depleted MCF7 cells. These results indicate the possible role of $E R \alpha$ in the regulation of ERR $\beta$ in breast cancer. Estrogen is required for the development of breast and ovaries in mammals [54], acts as a ligand for ERs [55], promotes cell proliferation and migration [56]. In our study we attributed the role of estrogen in the regulation of ERR $\beta$ in breast cancer cells. We confirmed that the expression of ERR $\beta$ is highly elevated in the presence of estrogen in ER + ve breast cancer cells (MCF7). However, in competition studies ERR $\beta$ expression was reduced with tamoxifen treatment along with estrogen.

Since ERs and ERRs show sequence similarity, there is a possibility of sharing of target genes and cross-talk between these receptors. In this study we detected two half ERE sites in the upstream region of $E R R \beta$ and proved the binding of ER $\alpha$ on those ERE sites both in-vitro and in-vivo. ER $\alpha$ interacts with various proteins such as Sp1 and Ap1 which can facilitate the binding of ER $\alpha$ on half ERE sites [57]. Sp1 stabilizes $E R \alpha$ dimer and co-operate the binding of $\mathrm{ER} \alpha$ on half EREs present on its target gene promoter $[58,59]$. Whereas, HMG1 interacts with ER $\alpha$ and stabilizes ER $\alpha$-ERE binding through which it enhances the transcription activity [60]. Since previous studies have suggested that $E R \alpha$ is an interacting partner of ERR $\beta$ [48], therefore we hypothesize that ERR $\beta$ might be playing an important role in the regulation of its own promoter by acting as facilitator of ER $\alpha$ to bind to the half ERE sites. ChIP assay and Re-ChIP provided enough evidenceses to confirm the self regulation of ERR $\beta$ through ER $\alpha$ in the presence of estrogen. Furthermore, luciferase assay confirmed the regulation of $E R R \beta$ by ER $\alpha$. Surprisingly, ERR $\beta$ alone 


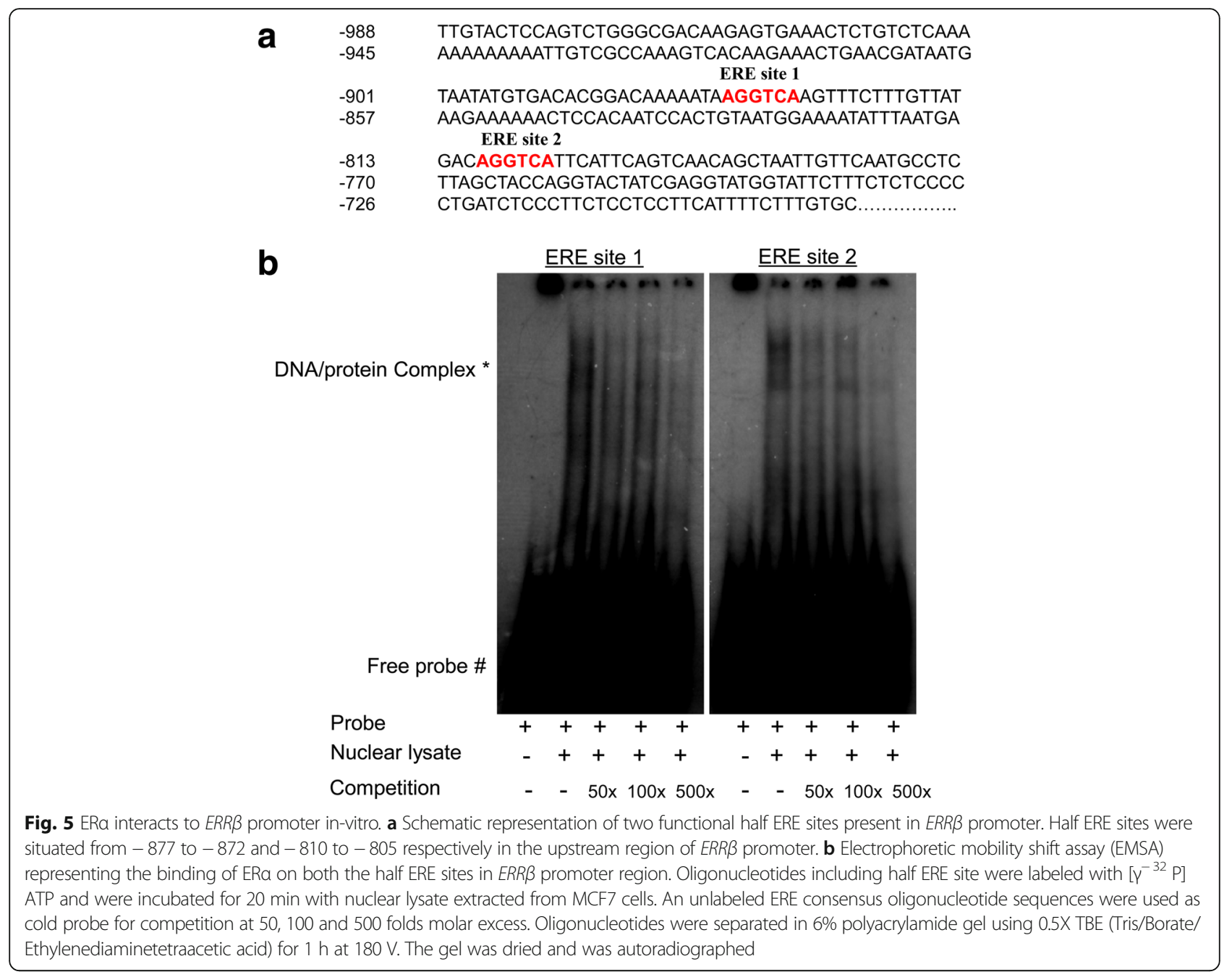

has no effect on promoter activity. These findings demonstrate that ER $\alpha$ can regulate the transcriptional activity of $E R R \beta$.

In normal cells the cell division is tightly regulated and a fine balance amongst the cell cycle modulators does exist [61]. The impairment of this fine balance is one of the major causes of cancer. p $21^{\text {cip }}$ is an inhibitor of cyclin dependent kinase belongs to cip and kip family [62], primarily inhibits CDK2 by which it can inhibit cell cycle progression $[63,64]$. p21 ${ }^{\text {cip }}$ arrests G1-G2 transition in cell cycle through binding to PCNA in P53 deficient cells [65]. p18 belongs to INK4 family and can inhibit cyclin dependent kinases potentially. Reduced levels of p18 were detected in hepatocellular carcinoma [66]. In this study, we have established the correlation between the expression of ERR $\beta$ and various cell cycle markers such as p21 $1^{\text {cip }}$, p18 and cyclin D1 in breast cancer cells. The elevated levels of p $21^{\text {cip }}$, p 18 and decreased expression of cyclin D1 in ectopically expressed ERR $\beta$ breast cancer cell lines were observed. Cell cycle analysis (FACS) provided enough evidence of cell cycle regulatory role of ERR $\beta$ in MCF7 cells. p $21^{\text {cip }}$ protein levels were directly correlated with the expression of ERR $\beta$ in prostate cancer cells and it has been proved that $\mathrm{p} 21^{\mathrm{cip}}$ is a direct target for ERR $\beta$ [36]. Interestingly $\mathrm{p} 21^{\text {cip }}$ was demonstrated as a direct target for both $E R R \alpha$ and ERR $\gamma$ and their protein levels were negatively correlated with each other $[67,68]$. Thus, not only for ERR $\beta, \mathrm{p} 21^{\text {cip }}$ is a direct target for all ERRs. Prostate and breast cancer cells showed inhibition of ERR $\alpha$ using XCT790 (inverse agonist) leads to reduction in cell proliferation [67]. However, ERR $\beta$ and ERR $\gamma$ were served as tumor suppressors in prostate cancer cells $[36,68]$. Recent studies also demonstrated the tumor suppressor role of ERR $\beta$ through BCAS2 in breast cancer cells [37]. Our results were in agreement with the previous studies and this cell cycle regulatory and tumor suppressor roles of ERR $\beta$ in breast cancer cells suggest that ERR $\beta$ can be considered as a potential therapeutic target for the treatment of breast cancer. 


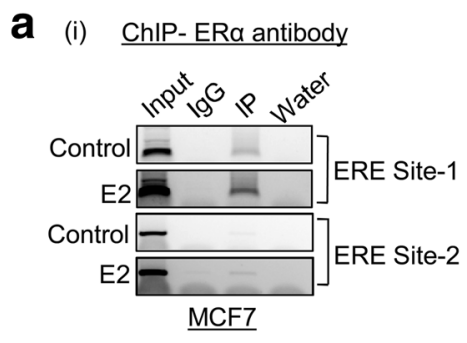

b

(i) ChIP- ERRß antibody

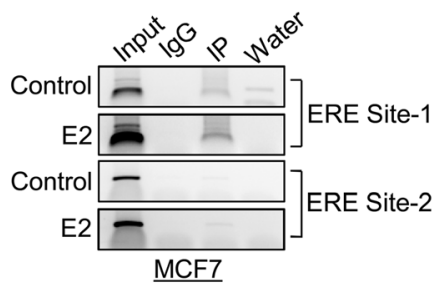

C

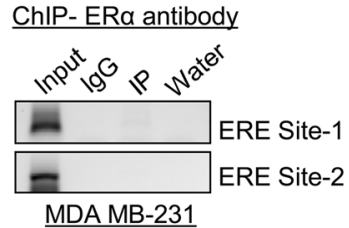

(ii)

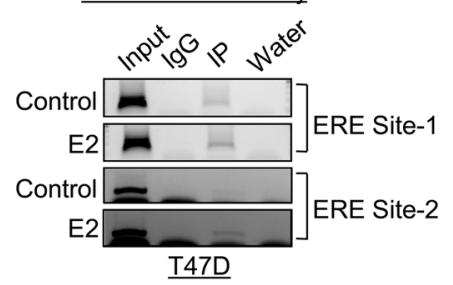

(ii)

$\underline{\text { ChIP- ERR } \beta \text { antibody }}$

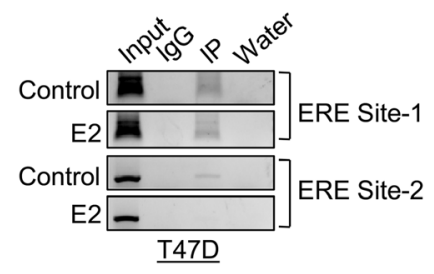

d

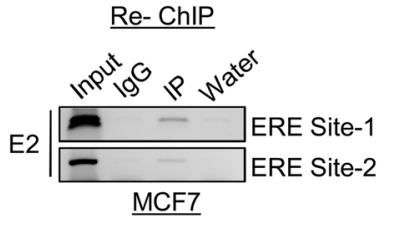

Fig. 6 Estrogen facilitates binding of ERR $\beta$ on half EREs through ERa. a ChIP assay showing ERa binding to half EREs on ERR $\beta$ promoter in-vivo in the presence of estrogen in (i) MCF7 and (ii) T47D cells. $\mathbf{b}$ ERR $\beta$ binding in the upstream region of ERR $\beta$ promoter upon estrogen treatment in (i) MCF7 and (ii) T47D cells. c ER-ve breast cancer cells (MDA-MB 231) showing no binding of ERa on ERR $\beta$ promoter and used as a negative control. d Re-ChIP shows binding of ERa and ERR $\beta$ heterodimer complex on half ERE sites present on ERR $\beta$ promoter

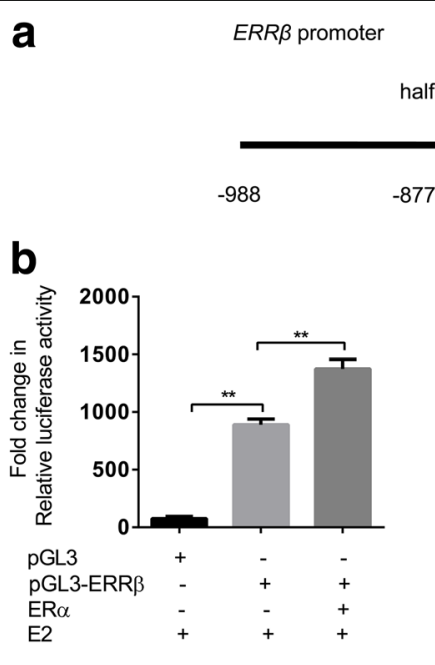

MCF7
C

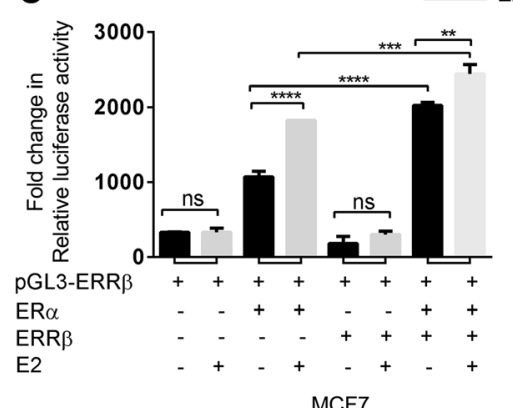

Fig. 7 Effect of $E R a$ and $E R R \beta$ on ERR $\beta$ promoter. a Schematic representation of ERR $\beta$ promoter showing two half ERE sites. b ERa regulates ERR $\beta$ classically in the presence of estrogen. c MCF7 cells were transfected with ERa, ERR $\beta$ along with ERR $\beta$ promoter and luciferase readings were obtained in the presence and absence of estrogen stimulation. Renilla readings were taken as a control and all the experiments were conducted in triplicates; statistical significance was analyzed using One-way ANOVA test and $p<0.05$ considered as significant (ns- no significance, ${ }^{*} p<0.05$, $\left.{ }^{* *} p<0.01,{ }^{* * *} p<0.001,{ }^{* * *} p<0.0001\right)$ 


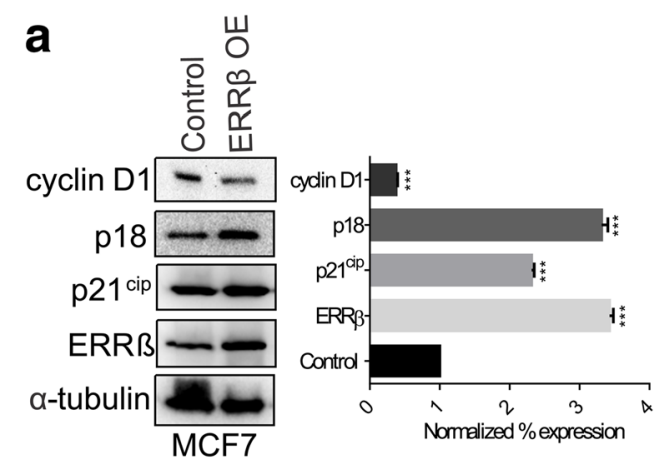

\section{b}
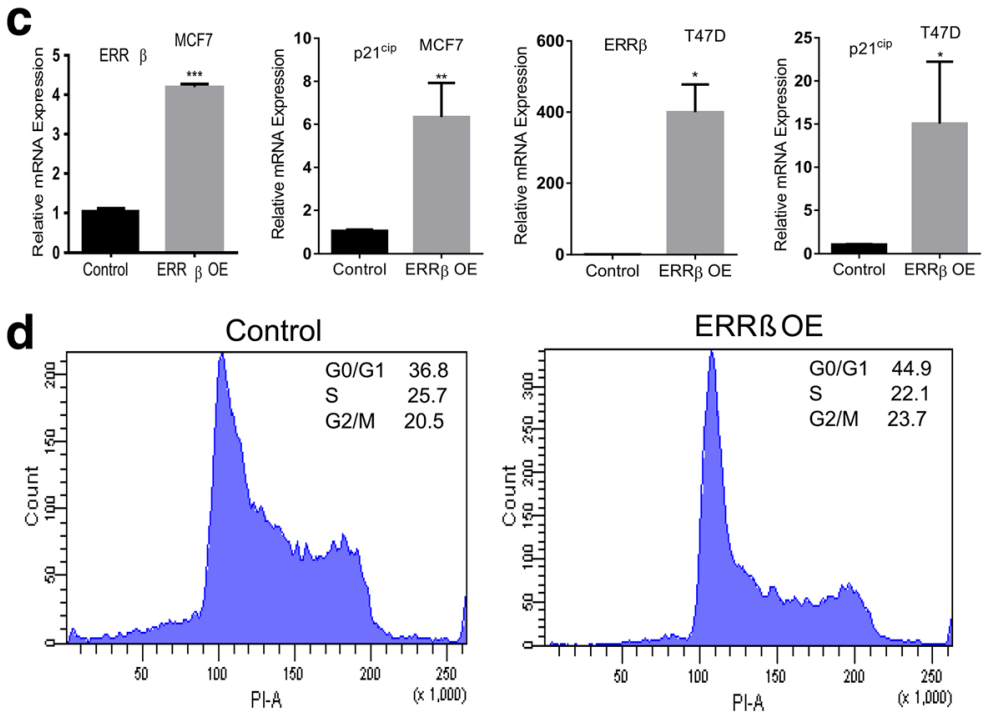

Fig. 8 ERR $\beta$ is a regulator of cell cycle and inhibition of ERR $\beta$ leads to cell proliferation. a Western blots and densitometry analysis showing changes in the expression of cell cycle markers, such as p21 $1^{\text {cip }}, \mathrm{p} 18$ and cyclin D1 upon the over expression of ERR $\beta$ in MCF7 cells. $\mathbf{b}, \mathbf{c}$ ERR $\beta$ was ectopically expressed in $E R+$ ve breast cancer cells, after $48 \mathrm{~h}$ the mRNA levels of p21 $1^{\mathrm{cip}}$ were examined by RT-PCR and RT-qPCR, p21 ${ }^{\mathrm{cip}}$ was significantly up-regulated. All the results were obtained from three independent experiments and each done in triplicates, 2-group unpaired t-test was used to obtain $p$-values and $p<0.05$ considered as significant $\left.{ }^{*} p<0.05,{ }^{* *} p<0.01,{ }^{* *} p<0.001,{ }^{* * *} p<0.0001\right)$. $\mathbf{d}$ Fluorescence- activated cell sorting assay (FACS) showing increase of cell fractions in G0/G1 phase upon ectopic expression of ERR $\beta$ in MCF7 cells

One might surprise with the tumor suppressive role of an estrogen induced gene. It is well established that estrogen promotes cell proliferation in ER + ve breast cancer cells but also induces the expression of p53 and BRCA1. Interestingly, not only p53 but also BRCA1 gene is associated with inhibition of cell growth, DNA repair and apoptosis [69-73]. P53 and BRCA1 both physically interact with $E R \alpha$ and inhibit ER $\alpha$-mediated transactivation [74, 75]. Recent studies also showed that estrogen up-regulate the expression of RERG a novel tumor suppressive gene which is highly expressed in ER + ve breast cancers [76]. In our study we showed that ERR $\beta$ is an estrogen responsive gene and it exhibits tumor suppressor role in breast cancer cells. Recent studies showed that ERR $\beta$ interacts with ER $\alpha$ in the presence of estrogen and ERR $\beta$ decrease the intranuclear mobility through which it can inhibit the transcriptional activity of ER $\alpha$ [48]. This phenomenon might be playing an important role in the inhibition of estrogen responsive target genes. Hormonal activation of tumor suppressive genes such as p53, BRCA1, RERG and ERR $\beta$ do play a vital role in the regulatory pathways that inhibit the estrogen induced cell growth and differentiation.

\section{Conclusions}

In our present study we have categorically demonstrated that ERR $\beta$ expression was down-regulated in the breast cancer patient samples in comparison with normal samples. High expression of ERR $\beta$ showed a significant favorable survival outcome in breast cancer. We showed for the first time that the expression of ERR $\beta$ is ER $\alpha$ 


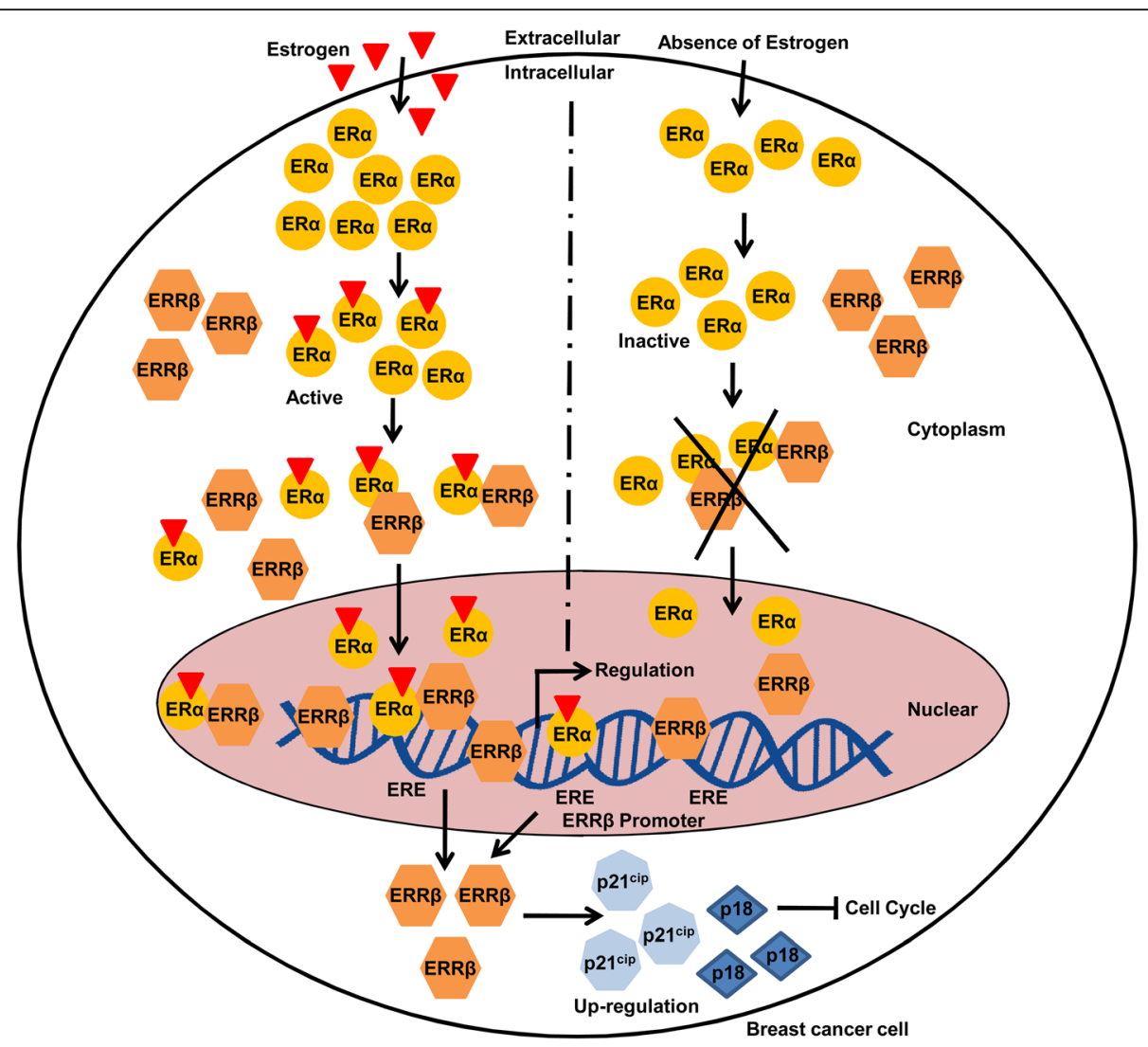

Fig. 9 Schematic representation of ERa classically regulating ERR $\beta$ and role of ERR $\beta$ in cell cycle regulation through p18 and p21 $1^{\text {cip }}$. In the presence of estrogen ERa gets activated and forms a heterodimer by interacting with ERR $\beta$. ERa alone or along with ERR $\beta$ in the form of heterodimer binds to the promoter region of ERR $\beta$ and up-regulates its promoter activity. ERR $\beta$ up-regulates cell cycle markers expression such as p21 cip and p18. p21 cip, p18 are cyclin dependent kinase inhibitors and halt cell cycle. Thus, our study suggests that the cell cycle regulating role of ERR $\beta$ by up-regulating $p 21^{\text {cip }}$ and $p 18$

dependent and stimulated by steroid hormone estrogen as observed in patient data and breast cancer cell lines. In vitro and In vivo studies proved that ERR $\beta$ is a direct target of ER $\alpha$. Cyclin D1, p21 $1^{\text {cip }}$ and p18 plays an important role in cell cycle and we also have established the correlation between the expression of ERR $\beta$ and the expression of these cell cycle modulators. Therefore our study proposes that ERR $\beta$ could be a possible tumor suppressor and can be used as therapeutic target in breast cancer.

\section{Abbreviations}

BC: Breast cancer; ChIP: Chromatin immunoprecipitation; DMEM: Dulbecco's modified Eagle's medium; E2: Estrogen; EMSA: Electrophoretic mobility shift assay; ER: Estrogen receptor; ERR: Estrogen related receptor; FBS: Fetal bovine serum; GAPDH: Glyceraldehyde-3- phosphate dehydrogenase; qRTPCR: Quantitative real-time polymerase chain reaction; RPMI 1640: Roswell Park Memorial Institute 1640; RT-PCR: Reverse transcription polymerase chain reaction; shRNA: Short hairpin RNA; TMA: Tissue microarray

\section{Acknowledgements}

BMK, SC and SS thank the Department of Biotechnology, Government of India for research fellowships. DRM thank Indian Council of Medical Research, Government of India for research fellowship. SKN thank the Council of
Scientific and Industrial Research, Government of India for research fellowship. We thank Dr. S. Senapati for extending his help regarding TMA related work. We thank Dr. Philippa Saunders, Director, MRC Centre for Reproductive Health, The Queen's Medical Research Institute, Edinburgh, for providing ERR $\beta$-YFP and ER $\alpha$-CFP constructs. We would like to thank Mr. Ravi Chandra Tagirasa and Mr. Sashi bhusana sahoo for extending their help in performing FACS and technical support respectively.

\section{Funding}

This work was supported by institutional core grant of Institute of Life Sciences, Department of Biotechnology, Government of India.

\section{Availability of data and materials}

All those named as authors confirmed the availability of data and materials. The supporting data are available from the corresponding author and will be provided upon reasonable request.

\section{Authors' contributions}

BMK, SC and SKM conceived and designed the study. BMK, SC, DRM, SKN performed the experiments, manuscript was written by BMK, SKM, SC and DRM. BMK and SS performed IHC and scoring was performed by AKA for TMA slides. SKM analyzed the data and all the authors have read and approved the final version of manuscript before publication.

Ethics approval and consent to participate

Materials and cell lines used in this study don't require an ethical approval. 


\section{Competing interests}

The authors declare that they have no competing interests.

\section{Publisher's Note}

Springer Nature remains neutral with regard to jurisdictional claims in published maps and institutional affiliations.

\section{Author details}

${ }^{1}$ Cancer Biology Lab, Institute of Life Sciences, Nalco Square, Chandrasekharpur, Bhubaneswar, Odisha 751023 , India. ${ }^{2}$ Present address: Department of Biochemistry and Molecular Biology, University of Nebraska Medical Center (UNMC), Omaha, NE, USA. ${ }^{3}$ Department of Gene Function \& Regulation, Institute of Life Sciences, Nalco square, Chandrasekharpur, Bhubaneswar, Odisha 751023, India. ${ }^{4}$ Tumor Microenvironment and Animal Models Lab, Department of Translational Research and Technology Development, Institute of Life Sciences, Nalco square, Chandrasekharpur, Bhubaneswar, Odisha 751023, India. ${ }^{5}$ Department of Pathology, Kalinga Institute of Medical Sciences, Chandaka Industrial Estate, KIIT Rd, Patia, Bhubaneswar, Odisha, India.

\section{Received: 1 November 2017 Accepted: 18 May 2018}

\section{Published online: 30 May 2018}

\section{References}

1. National Breast Cancer Foundation, INC. Breast Cancer Facts. http://www. nationalbreastcancer.org/breast-cancer-facts

2. American Cancer Society: breast cancer facts and figures 2016-2017. https:// www.cancer.org/cancer/breast-cancer/about/how-common-is-breast-cancer. html

3. Perou CM, Sorlie T, Eisen MB, van de Rijn M, Jeffrey SS, Rees CA, Pollack JR, Ross DT, Johnsen H, Akslen LA, et al. Molecular portraits of human breast tumours. Nature. 2000;406(6797):747-52

4. Lewis-Wambi JS, Jordan VC. Treatment of postmenopausal breast cancer with Selective Estrogen Receptor Modulators (SERMs). Breast Dis. 2005;24:93-105.

5. Hawkins MB, Thornton JW, Crews D, Skipper JK, Dotte A, Thomas P. Identification of a third distinct estrogen receptor and reclassification of estrogen receptors in teleosts. Proc Natl Acad Sci U S A. 2000;97(20):10751-6.

6. Gronemeyer $\mathrm{H}$. Transcription activation by estrogen and progesterone receptors. Annu Rev Genet. 1991;25:89-123.

7. Pettersson K, Grandien K, Kuiper GG, Gustafsson JA. Mouse estrogen receptor beta forms estrogen response element-binding heterodimers with estrogen receptor alpha. Mol Endocrinol. 1997;11(10):1486-96.

8. Cowley SM, Hoare S, Mosselman S, Parker MG. Estrogen receptors alpha and beta form heterodimers on DNA. J Biol Chem. 1997:272(32):19858-62.

9. Tremblay GB, Tremblay A, Labrie F, Giguere V. Dominant activity of activation function 1 (AF-1) and differential stoichiometric requirements for AF-1 and -2 in the estrogen receptor alpha-beta heterodimeric complex. Mol Cell Biol. 1999:19(3):1919-27.

10. Wu WF, Tan XJ, Dai YB, Krishnan V, Warner M, Gustafsson JA. Targeting estrogen receptor beta in microglia and T cells to treat experimental autoimmune encephalomyelitis. Proc Natl Acad Sci U S A. 2013;110(9):3543-8.

11. Thomas C, Gustafsson JA. The different roles of ER subtypes in cancer biology and therapy. Nat Rev Cancer. 2011;11(8):597-608.

12. Cooper JA, Rohan TE, Cant EL, Horsfall DJ, Tilley WD. Risk factors for breast cancer by oestrogen receptor status: a population-based case-control study. Br J Cancer. 1989;59(1):119-25.

13. Lazennec G, Bresson D, Lucas A, Chauveau C, Vignon F. ER beta inhibits proliferation and invasion of breast cancer cells. Endocrinology. 2001; 142(9):4120-30.

14. Paruthiyil S, Parmar $H$, Kerekatte V, Cunha GR, Firestone GL, Leitman DC. Estrogen receptor beta inhibits human breast cancer cell proliferation and tumor formation by causing a G2 cell cycle arrest. Cancer Res. 2004;64(1):423-8.

15. Strom A, Hartman J, Foster JS, Kietz S, Wimalasena J, Gustafsson JA. Estrogen receptor beta inhibits 17 beta-estradiol-stimulated proliferation of the breast cancer cell line T47D. Proc Natl Acad Sci U S A. 2004; 101(6):1566-71

16. Vegeto E, Belcredito S, Etteri S, Ghisletti S, Brusadelli A, Meda C, Krust A, Dupont S, Ciana P, Chambon P, et al. Estrogen receptor-alpha mediates the brain antiinflammatory activity of estradiol. Proc Natl Acad Sci U S A. 2003; 100(16):9614-9.
17. Sun P, Wei L, Denkert C, Lichtenegger W, Sehouli J. The orphan nuclear receptors, estrogen receptor-related receptors: their role as new biomarkers in gynecological cancer. Anticancer Res. 2006;26(2C):1699-706.

18. Giguere V. Orphan nuclear receptors: from gene to function. Endocr Rev. 1999;20(5):689-725.

19. Enmark E, Gustafsson JA. Orphan nuclear receptors-the first eight years. Mol Endocrinol. 1996;10(11):1293-307.

20. Zhang Z, Chen K, Shih JC, Teng CT. Estrogen-related receptors-stimulated monoamine oxidase B promoter activity is down-regulated by estrogen receptors. Mol Endocrinol. 2006;20(7):1547-61.

21. Lu D, Kiriyama Y, Lee KY, Giguere V. Transcriptional regulation of the estrogen-inducible pS2 breast cancer marker gene by the ERR family of orphan nuclear receptors. Cancer Res. 2001;61(18):6755-61.

22. Giguere $V$, Yang $N$, Segui $P$, Evans RM. Identification of a new class of steroid hormone receptors. Nature. 1988:331(6151):91-4.

23. Eudy JD, Yao S, Weston MD, Ma-Edmonds M, Talmadge CB, Cheng JJ, Kimberling WJ, Sumegi J. Isolation of a gene encoding a novel member of the nuclear receptor superfamily from the critical region of usher syndrome type lla at 1q41. Genomics. 1998;50(3):382-4.

24. Hong H, Yang L, Stallcup MR. Hormone-independent transcriptional activation and coactivator binding by novel orphan nuclear receptor ERR3. J Biol Chem. 1999;274(32):22618-26.

25. Chen F, Zhang Q, McDonald T, Davidoff MJ, Bailey W, Bai C, Liu Q, Caskey CT. Identification of two hERR2-related novel nuclear receptors utilizing bioinformatics and inverse PCR. Gene. 1999;228(1-2):101-9.

26. Johnston SD, Liu X, Zuo F, Eisenbraun TL, Wiley SR, Kraus RJ, Mertz JE. Estrogen-related receptor alpha 1 functionally binds as a monomer to extended half-site sequences including ones contained within estrogenresponse elements. Mol Endocrinol. 1997;11(3):342-52.

27. Vanacker JM, Pettersson K, Gustafsson JA, Laudet V. Transcriptional targets shared by estrogen receptor- related receptors (ERRs) and estrogen receptor (ER) alpha, but not by ERbeta. EMBO J. 1999:18(15):4270-9.

28. Bonnelye E, Vanacker JM, Dittmar T, Begue A, Desbiens X, Denhardt DT, Aubin JE, Laudet $\mathrm{V}$, Fournier $\mathrm{B}$. The ERR-1 orphan receptor is a transcriptional activator expressed during bone development. Mol Endocrinol. 1997:11(7):905-16.

29. Sladek R, Bader JA, Giguere V. The orphan nuclear receptor estrogen-related receptor alpha is a transcriptional regulator of the human medium-chain acyl coenzyme a dehydrogenase gene. Mol Cell Biol. 1997;17(9):5400-9.

30. Giguere V. Transcriptional control of energy homeostasis by the estrogenrelated receptors. Endocr Rev. 2008;29(6):677-96.

31. Bookout AL, Jeong Y, Downes M, Yu RT, Evans RM, Mangelsdorf DJ. Anatomical profiling of nuclear receptor expression reveals a hierarchical transcriptional network. Cell. 2006;126(4):789-99.

32. Vega RB, Kelly DP. A role for estrogen-related receptor alpha in the control of mitochondrial fatty acid beta-oxidation during brown adipocyte differentiation. J Biol Chem. 1997:272(50):31693-9.

33. Huss JM, Imahashi K, Dufour CR, Weinheimer CJ, Courtois M, Kovacs A, Giguere $V$, Murphy E, Kelly DP. The nuclear receptor ERRalpha is required for the bioenergetic and functional adaptation to cardiac pressure overload. Cell Metab. 2007:6(1):25-37.

34. Pettersson K, Svensson K, Mattsson R, Carlsson B, Ohlsson R, Berkenstam A. Expression of a novel member of estrogen response element-binding nuclear receptors is restricted to the early stages of chorion formation during mouse embryogenesis. Mech Dev. 1996:54(2):211-23.

35. Collin RW, Kalay E, Tariq M, Peters T, van der Zwaag B, Venselaar H, Oostrik J, Lee K, Ahmed ZM, Caylan R, et al. Mutations of ESRRB encoding estrogenrelated receptor beta cause autosomal-recessive nonsyndromic hearing impairment DFNB35. Am J Hum Genet. 2008;82(1):125-38.

36. Yu S, Wong YC, Wang XH, Ling MT, Ng CF, Chen S, Chan FL. Orphan nuclear receptor estrogen-related receptor-beta suppresses in vitro and in vivo growth of prostate cancer cells via p21(WAF1/CIP1) induction and as a potential therapeutic target in prostate cancer. Oncogene. 2008;27(23): 3313-28.

37. Sengupta D, Bhargava DK, Dixit A, Sahoo BS, Biswas S, Biswas G, Mishra SK ERRbeta signalling through FST and BCAS2 inhibits cellular proliferation in breast cancer cells. Br J Cancer. 2014;110(8):2144-58.

38. Kleiner HE, Krishnan P, Tubbs J, Smith M, Meschonat C, Shi R, LoweryNordberg M, Adegboyega P, Unger M, Cardelli J, et al. Tissue microarray analysis of elF4E and its downstream effector proteins in human breast cancer. J Exp Clin Cancer Res. 2009;28:5. 
39. Kenny PA, Lee GY, Myers CA, Neve RM, Semeiks JR, Spellman PT, Lorenz K, Lee EH, Barcellos-Hoff MH, Petersen OW, et al. The morphologies of breast cancer cell lines in three-dimensional assays correlate with their profiles of gene expression. Mol Oncol. 2007;1(1):84-96.

40. Debnath J, Muthuswamy SK, Brugge JS. Morphogenesis and oncogenesis of MCF-10A mammary epithelial acini grown in three-dimensional basement membrane cultures. Methods. 2003;30(3):256-68.

41. Chaudhary S, Madhukrishna B, Adhya AK, Keshari S, Mishra SK Overexpression of caspase 7 is ERalpha dependent to affect proliferation and cell growth in breast cancer cells by targeting p21(Cip). Oncogenesis. 2016:5:e219.

42. Strauss WM. Preparation of genomic DNA from mammalian tissue. Current protocols in immunology. 2001;Chapter 10:Unit 1012.

43. Listerman I, Sapra AK, Neugebauer KM. Cotranscriptional coupling of splicing factor recruitment and precursor messenger RNA splicing in mammalian cells. Nat Struct Mol Biol. 2006;13(9):815-22.

44. Truax AD, Greer SF. ChIP and re-ChIP assays: investigating interactions between regulatory proteins, histone modifications, and the DNA sequences to which they bind. Methods Mol Biol. 2012;809:175-88.

45. Tourigny A, Charbonneau F, Xing P, Boukrab R, Rousseau G, St-Arnaud R, Brezniceanu ML. CYP24A1 exacerbated activity during diabetes contributes to kidney tubular apoptosis via caspase-3 increased expression and activation. PLoS One. 2012;7(10):e48652.

46. Heckler MM, Zeleke TZ, Divekar SD, Fernandez Al, Tiek DM, Woodrick J, Farzanegan A, Roy R, Uren A, Mueller SC, et al. Antimitotic activity of DY131 and the estrogen-related receptor beta 2 (ERRbeta2) splice variant in breast cancer. Oncotarget. 2016;7(30):47201-20.

47. Chanrion M, Negre V, Fontaine H, Salvetat N, Bibeau F, Mac Grogan G, Mauriac L, Katsaros D, Molina F, Theillet C, et al. A gene expression signature that can predict the recurrence of tamoxifen-treated primary breast cancer. Clin Cancer Res. 2008;14(6):1744-52.

48. Tanida T, Matsuda Kl, Yamada S, Hashimoto T, Kawata M. Estrogen-related receptor beta reduces the subnuclear mobility of estrogen receptor alpha and suppresses estrogen-dependent cellular function. J Biol Chem. 2015; 290(19):12332-45.

49. Mandal S, Davie JR. Estrogen regulated expression of the p21 Waf1/Cip1 gene in estrogen receptor positive human breast cancer cells. J Cell Physiol. 2010;224(1):28-32.

50. Duffy MJ. Estrogen receptors: role in breast cancer. Crit Rev Clin Lab Sci. 2006:43(4):325-47.

51. Felzen V, Hiebel C, Koziollek-Drechsler I, Reissig S, Wolfrum U, Kogel D, Brandts C, Behl C, Morawe T. Estrogen receptor alpha regulates noncanonical autophagy that provides stress resistance to neuroblastoma and breast cancer cells and involves BAG3 function. Cell Death Dis. 2015;6:e1812.

52. Bombail V, MacPherson S, Critchley HO, Saunders PT. Estrogen receptor related beta is expressed in human endometrium throughout the normal menstrual cycle. Hum Reprod. 2008;23(12):2782-90.

53. van den Berg DL, Zhang W, Yates A, Engelen E, Takacs K, Bezstarosti K, Demmers J, Chambers I, Poot RA. Estrogen-related receptor beta interacts with Oct4 to positively regulate Nanog gene expression. Mol Cell Biol. 2008; 28(19):5986-95.

54. Russo $\mathrm{H}$, Russo J. Role of hormones in mammary cancer initiation and progression. J Mammary Gland Biol Neoplasia. 1998;3(1):49-61.

55. Tamrazi A, Carlson KE, Daniels JR, Hurth KM, Katzenellenbogen JA. Estrogen receptor dimerization: ligand binding regulates dimer affinity and dimer dissociation rate. Mol Endocrinol. 2002;16(12):2706-19.

56. Laidlaw IJ, Clarke RB, Howell A, Owen AW, Potten CS, Anderson E. The proliferation of normal human breast tissue implanted into athymic nude mice is stimulated by estrogen but not progesterone. Endocrinology. 1995;136(1):164-71.

57. Klinge CM. Estrogen receptor interaction with estrogen response elements. Nucleic Acids Res. 2001;29(14):2905-19.

58. Petz LN, Nardulli AM. Sp1 binding sites and an estrogen response element half-site are involved in regulation of the human progesterone receptor a promoter. Mol Endocrinol. 2000;14(7):972-85.

59. Dahlman-Wright K, Qiao Y, Jonsson P, Gustafsson JA, Williams C, Zhao C. Interplay between AP-1 and estrogen receptor alpha in regulating gene expression and proliferation networks in breast cancer cells. Carcinogenesis. 2012;33(9):1684-91.
60. Zhang CC, Krieg S, Shapiro DJ. HMG-1 stimulates estrogen response element binding by estrogen receptor from stably transfected HeLa cells. Mol Endocrinol. 1999;13(4):632-43.

61. Barnum KJ, O'Connell MJ. Cell cycle regulation by checkpoints. Methods Mol Biol. 2014;1170:29-40.

62. Mandal M, Bandyopadhyay D, Goepfert TM, Kumar R. Interferon-induces expression of cyclin-dependent kinase-inhibitors p21WAF1 and p27Kip1 that prevent activation of cyclin-dependent kinase by CDK-activating kinase (CAK). Oncogene. 1998;16(2):217-25.

63. Smits VA, Klompmaker R, Vallenius T, Rijksen G, Makela TP, Medema RH. p21 inhibits Thr161 phosphorylation of Cdc2 to enforce the G2 DNA damage checkpoint. J Biol Chem. 2000;275(39):30638-43.

64. Abbas T, Jha S, Sherman NE, Dutta A. Autocatalytic phosphorylation of CDK2 at the activating Thr160. Cell Cycle. 2007;6(7):843-52.

65. Cayrol C, Knibiehler M, Ducommun B. p21 binding to PCNA causes G1 and G2 cell cycle arrest in p53-deficient cells. Oncogene. 1998;16(3):311-20.

66. Morishita A, Masaki T, Yoshiji H, Nakai S, Ogi T, Miyauchi Y, Yoshida S, Funaki T, Uchida N, Kita Y, et al. Reduced expression of cell cycle regulator p18(INK4C) in human hepatocellular carcinoma. Hepatology. 2004;40(3):677-86.

67. Bianco S, Lanvin O, Tribollet V, Macari C, North S, Vanacker JM. Modulating estrogen receptor-related receptor-alpha activity inhibits cell proliferation. J Biol Chem. 2009:284(35):23286-92.

68. Yu S, Wang X, Ng CF, Chen S, Chan FL. ERRgamma suppresses cell proliferation and tumor growth of androgen-sensitive and androgeninsensitive prostate cancer cells and its implication as a therapeutic target for prostate cancer. Cancer Res. 2007;67(10):4904-14.

69. Hurd C, Khattree N, Alban P, Nag K, Jhanwar SC, Dinda S, Moudgil VK. Hormonal regulation of the p53 tumor suppressor protein in T47D human breast carcinoma cell line. J Biol Chem. 1995;270(48):28507-10.

70. Hurd C, Dinda S, Khattree N, Moudgil VK. Estrogen-dependent and independent activation of the $\mathrm{P} 1$ promoter of the $\mathrm{p} 53$ gene in transiently transfected breast cancer cells. Oncogene. 1999;18(4):1067-72.

71. Hurd C, Khattree N, Dinda S, Alban P, Moudgil VK. Regulation of tumor suppressor proteins, p53 and retinoblastoma, by estrogen and antiestrogens in breast cancer cells. Oncogene. 1997;15(8):991-5.

72. Spillman MA, Bowcock AM. BRCA1 and BRCA2 mRNA levels are coordinately elevated in human breast cancer cells in response to estrogen. Oncogene. 1996;13(8):1639-45.

73. Gudas JM, Nguyen H, Li T, Cowan KH. Hormone-dependent regulation of BRCA1 in human breast cancer cells. Cancer Res. 1995;55(20):4561-5.

74. Fan S, Wang J, Yuan R, Ma Y, Meng Q, Erdos MR, Pestell RG, Yuan F, Auborn $\mathrm{KJ}$, Goldberg ID, et al. BRCA1 inhibition of estrogen receptor signaling in transfected cells. Science. 1999;284(5418):1354-6.

75. Liu G, Schwartz JA, Brooks SC. Estrogen receptor protects p53 from deactivation by human double minute-2. Cancer Res. 2000;60(7):1810-4.

76. Finlin BS, Gau CL, Murphy GA, Shao H, Kimel T, Seitz RS, Chiu YF, Botstein D, Brown PO, Der CJ, et al. RERG is a novel ras-related, estrogen-regulated and growth-inhibitory gene in breast cancer. J Biol Chem. 2001;276(45):42259-67.

\section{Ready to submit your research? Choose BMC and benefit from:}

- fast, convenient online submission

- thorough peer review by experienced researchers in your field

- rapid publication on acceptance

- support for research data, including large and complex data types

- gold Open Access which fosters wider collaboration and increased citations

- maximum visibility for your research: over $100 \mathrm{M}$ website views per year

At BMC, research is always in progress.

Learn more biomedcentral.com/submissions 